\title{
Otocinclus batmani, a new species of hypoptopomatine catfish (Siluriformes: Loricariidae) from Colombia and Peru
}

\author{
Pablo Lehmann A.
}

\begin{abstract}
A new species of the hypoptopomatine catfish genus Otocinclus is described from two localities in the upper Río Amazonas basin: a tributary of the Río Puré in Colombia and two tributaries to the Río Amazonas near Iquitos in Peru. The new taxon can be easily distinguished from all congeners, except Otocinclus cocama, by having a single, intensely pigmented, vertical Wshaped caudal fin spot and by having three discrete dark bands on dorsum, between the dorsal-fin base and the caudal fin. Otocinclus batmani differs from $O$. cocama by the absence of vertically elongated blotches from the dorsal midline to the ventral border of flanks, and by lacking a posterior extension of black pigmentation on the base of two central caudal-fin rays. Phylogenetic relationships of the new species are investigated and it is possibly more closely related to a clade formed by $O$. huaorani, O. mariae, O. bororo, O. mura, and O. cocama.

Uma nova espécie de bagre hypoptopomatineo do gênero Otocinclus é descrita de duas localidades na bacia do alto rio Amazonas: um tributário do rio Puré na Colômbia e dois igarapés tributários do rio Amazonas próximo a Iquitos no Peru. O novo táxon pode ser facilmente distinguido dos demais congêneres, exceto Otocinclus cocama, por uma mancha vertical em forma de W, densamente pigmentada localizada na porção posterior da nadadeira caudal, e pela presença de três bandas discretas escuras no dorso, entre a base da nadadeira dorsal e a nadadeira caudal. De Otocinclus cocama ela é diferenciada pelo padrão de colorido composto de uma grande faixa escura lateral ( $v s$. faixas verticais alongadas nos flancos) e pela ausência de pigmentação negra prolongada na base dos dois raios centrais da nadadeira caudal. As relações filogenéticas da nova espécie são investigadas e ela é possivelmente mais proximamente relacionada a um clado formado por $O$. huaorani, O. mariae, $O$. bororo, O. mura e O. cocama.
\end{abstract}

Key words: Neotropical, Systematics, Taxonomy, Freshwater, Corroncho, Cascudinho, Catfish.

\section{Introduction}

The genus Otocinclus Cope, 1871 is composed of 16 species of small (less than $60 \mathrm{~mm} \mathrm{SL}$ ) freshwater catfishes distributed in the Neotropics from Colombia to northern Argentina, occurring in tributaries to the east of the Andes (Schaefer, 2003). Schaefer (1997) revised the genus and recognized 13 species. Britto \& Moreira (2002) described Otocinclus tapirape from the rio Araguaia basin in central Brazil and reexamined the phylogenetic relationships within the genus.Axenrot \& Kullander (2003) recently added $O$. mimulus from the Río Parana in Paraguay, and Reis (2004) described O. cocama from the Río Ucayali basin in Peru. These fishes are mostly herbivorous, are typically diurnal, and are usually found at or near the water surface, typically in close association with marginal vegetation or subsurface structures (Schaefer, 2003). Otocinclus is a basal member of the tribe Hypoptopomatini and is believed to be monophyletic (Schaefer, 1997) on the basis of several synapomorphies, especially of the cranial and hyobranchial skeleton, dorsal gill arch musculature, and gut. Otocinclus shares with Acestridium, Hypoptopoma, Nannoptopoma, Niobicthys, Oxyropsis, and a new taxon from Brazil and Colombia, a reduced preopercle. Schaefer (1997) also provided a set of hypotheses for its biogeographic history. The phylogenetic relationships among the hypoptopomatines are currently under study, and the genus Otocinclus may eventually be relocated. In this paper, Otocinclus batmani is described from Colombia and Peru in the upper Amazon River basin.

\section{Material and Methods}

Counts, morphometrics, and nomenclature follow Schaefer (1997), Britto \& Moreira (2002), Douglas et al. (2002), and Axenrot \& Kullander (2003). Specimens studied were cleared and stained (c\&s) using the methods of Taylor \& Van Dyke

Laboratório de Ictiologia, Pontifícia Universidade Católica do Rio Grande do Sul. Av. Ipiranga, 6681, Caixa Postal 1429, 90619-900 Porto Alegre, RS, Brazil; and Museo de Historia Natural - Universidad del Cauca (MHNUC), Popayán, Colombia. E-mail: lehmanncatfish@gmail.com 
(1985). Counts listed in the text are followed by their frequency in parentheses, an asterisk indicating values for the holotype. The specimens examined belong to the following institutions: ANSP, Academy of Natural Sciences, Philadelphia; ICNMHN, Instituto de Ciencias Naturales, Museo de Historia Natural, Universidad Nacional de Colombia, Bogotá; MCNG, Museo de Ciências Naturales, Guanare; MCP, Museu de Ciências e Tecnologia, Pontifícia Universidade Católica do Rio Grande do Sul, Porto Alegre; MHNUC, Museo de Historia Natural de la Universidad del Cauca, Popayán; MZUSP, Museu de Zoologia da Universidade de São Paulo, São Paulo; NRM, Naturhistoriska Riksmuseum, Stockholm; UFRGS, Universidade Federal do Rio Grande do Sul, Porto Alegre; and UFRJ, Universidade Federal do Rio de Janeiro. Geographic descriptors (rio, arroio, etc.) are in Portuguese when referring to Brazilian localities of in Spanish (Río, Quebrada, Arroyo, etc.) when referring to non-Brazilian localities.

\section{Otocinclus batmani, new species}

Fig. 1

Holotype. ICNMHN 6721, 28.5 mm SL, male, Colombia, Amazonas, small stream tributary of Río Puré, Río Japurá drainage, upper Río Amazonas basin, 0207’05"S 69³7’ 50"W, 28 Dec 1999, John D. Lynch.

Paratypes. ICNMHN 6722, 1, 36.7 mm SL, MCP 34087, 1 c\&s, $27.7 \mathrm{~mm} \mathrm{SL}$, and MHNUC 474, 1, $28.4 \mathrm{~mm} \mathrm{SL}$, collected with the holotype. ANSP 178616, 4, 35.0-36.7 mm SL, 1 c\&s, $38.4 \mathrm{~mm} \mathrm{SL}$, Peru, Loreto, Provincia de Maynas, small creek 25 miles south of Iquitos, tributary of Río Amazonas, $04^{\circ} 14^{\prime} 45^{\prime \prime S ~ 7324 ' 57 " W, ~} 11$ Aug 2001,M. H. Sabaj, M. W. Littmann \& J. G. Stewart. MCP 28172, 1, $23.2 \mathrm{~mm}$ SL, Peru, Loreto, Nauta, creek $62 \mathrm{~km} \mathrm{SW}$ of Iquitos on road to Nauta, tributary of Río Amazonas, $04^{\circ} 15^{\prime} 33$ "S 73³0’11"W, 6 Aug 2000, J. Albert, R. E. Reis \& W. Crampton.

Diagnosis. The new species is distinguished from all other Otocinclus species, except $O$. cocama, by having a single, intensely pigmented, vertical $\mathrm{W}$-shaped caudal fin spot and by having three discrete dark bands on dorsum, between the dorsal-fin base and the caudal fin. Otocinclus batmani differs from the O. cocama by the absence of vertically elongated blotches from the dorsal midline to the ventral border of flanks, and by lacking the posterior extension of black pigmentation on the base of two central caudal-fin rays. The new species is also distinguished from most Otocinclus spe- cies, except $O$. bororo, O. cocama, O. mariae, O. mura, and $O$. huaorani, by having 20 or more teeth in both the premaxilla and dentary ( $v s$. less that 20 in all other species). Despite based on limited sampling (10 specimens) additional diagnostic morphometric data are presented in Table 1.

Description. Counts and proportional metrics given in Table 2. Standard length of examined specimens 23.2-36.7 mm. Dorsal profile of head from snout tip to dorsal-fin origin smoothly convex; straight between anterior margin of frontals and posterior supraoccipital tip. Dorsal profile of trunk from dorsalfin origin to dorsal procurrent caudal-fin rays slightly concave. Ventral profile of head and abdomen from snout tip to pelvic-fin base straight, transversely flat. Ventral profile of trunk straight between pelvic-fin base and anal-fin origin, concave between anal-fin origin and caudal peduncle. Caudal peduncle slightly rectangular in cross section. Snout tip smoothly rounded. Eyes moderately large, orbit center positioned approximately midway between snout tip and posterior process of pterotic-supracleithrum. Iris flap absent. Lateral ethmoid with expanded subnasal lamina.

Total plates in median lateral series 23. Lateral line discontinuous; anterior field of canal-bearing lateral line with $6^{*}(6)$ or 7(4) plates; posterior field with 8(3) or $9 *(7)$ plates and separated from anterior field by gap of $6(4)$ or $7 *(6)$ non canalbearing plates. Greatest body depth at dorsal-fin origin. Dorsal fin when depressed reaching to vertical through posterior third of anal fin. Pectoral fin reaching to proximal third of pelvic-fin length; pelvic fin almost reaching to anal-fin origin.

Abdomen with paired series of 7(5) or $8 *(5)$ large, rectangular, median plates arranged in irrregular series and becoming smaller and more irregularly shaped posteriorly; pre-anal plate well developed, continuous with median abdominal plates only in specimens above $30 \mathrm{~mm}$ SL.

Arrector fossa closed. Odontodes evenly distributed and regularly arranged on head and body; those on margins of snout only slightly larger than those on remainder of head. Enlarged odontodes along distal portion of unbranched rays of all fins, procurrent rays, and edges of caudal peduncle. Teeth bifid, with ovoid major medial cusp and small triangular minor, lateral cusp. Premaxillary teeth 23(1), 26*(3), 27(1), 29(2), 30(2), and 31(1). Mandibular teeth 19(3), 21(1), 22*(1), 24(1), 27(2), and 28(2). Oral disk ovoid, papillose. Maxillary barbel present with short free portion.

Table 1. Diagnostic morphometric data of Otocinclus batmani compared with closest congeners. Values for $O$. mariae, $O$. huaorani, O. mura, and O. bororo from Schaefer (1997), and for O. cocama from Reis (2004). (1) Percent of standard length; (2) percent of head length.

\begin{tabular}{|c|c|c|c|c|c|c|c|c|c|c|c|c|}
\hline & \multicolumn{2}{|c|}{$\begin{array}{c}\text { O. batmani } \\
\mathrm{N}=10 \\
\text { Upper Amazon } \\
\text { River }\end{array}$} & \multicolumn{2}{|c|}{$\begin{array}{c}\text { O. cocama } \\
\mathrm{N}=16 \\
\text { Upper Amazon } \\
\text { River }\end{array}$} & \multicolumn{2}{|c|}{$\begin{array}{c}\text { O. mariae } \\
\mathrm{N}=29 \\
\text { Lower Amazon, } \\
\text { Upper Madeira and } \\
\text { Paraguay } \\
\end{array}$} & \multicolumn{2}{|c|}{$\begin{array}{c}\text { O. huaorani } \\
\mathrm{N}=16 \\
\text { Upper Amazon and } \\
\text { Orinoco }\end{array}$} & \multicolumn{2}{|c|}{$\begin{array}{c}\text { O. mura } \\
\text { N=9 } \\
\text { Middle Amazon }\end{array}$} & \multicolumn{2}{|c|}{$\begin{array}{c}\text { O. bororo } \\
\mathrm{N}=9 \\
\text { Paraguay }\end{array}$} \\
\hline & Range & Mean & Range & Mean & Range & Mean & Range & Mean & Range & Mean & Range & Mean \\
\hline Standard length $(\mathrm{mm})$ & $23.2-36.7$ & 28.9 & $29.6-43.8$ & 38.2 & $21.4-32.6$ & 24.2 & $19.3-33.5$ & 29.1 & $20.7-36.1$ & 36.1 & $20.2-30.9$ & 30.9 \\
\hline Head Length $^{(1)}$ & $25.1-35.5$ & 29.1 & $27.8-38.6$ & 30.9 & $15.5-24.5$ & 24.3 & $15.5-25.1$ & 22.7 & $19.4-22.7$ & 22.2 & $18.2-21.0$ & 20.5 \\
\hline Orbit diameter ${ }^{(2)}$ & $21.1-27.4$ & 24.7 & $18.5-25.8$ & 22.8 & $30.4-37.3$ & 30.4 & $29.3-36.3$ & 29.7 & $32.5-38.9$ & 22.2 & $30.2-37.9$ & 32.1 \\
\hline
\end{tabular}




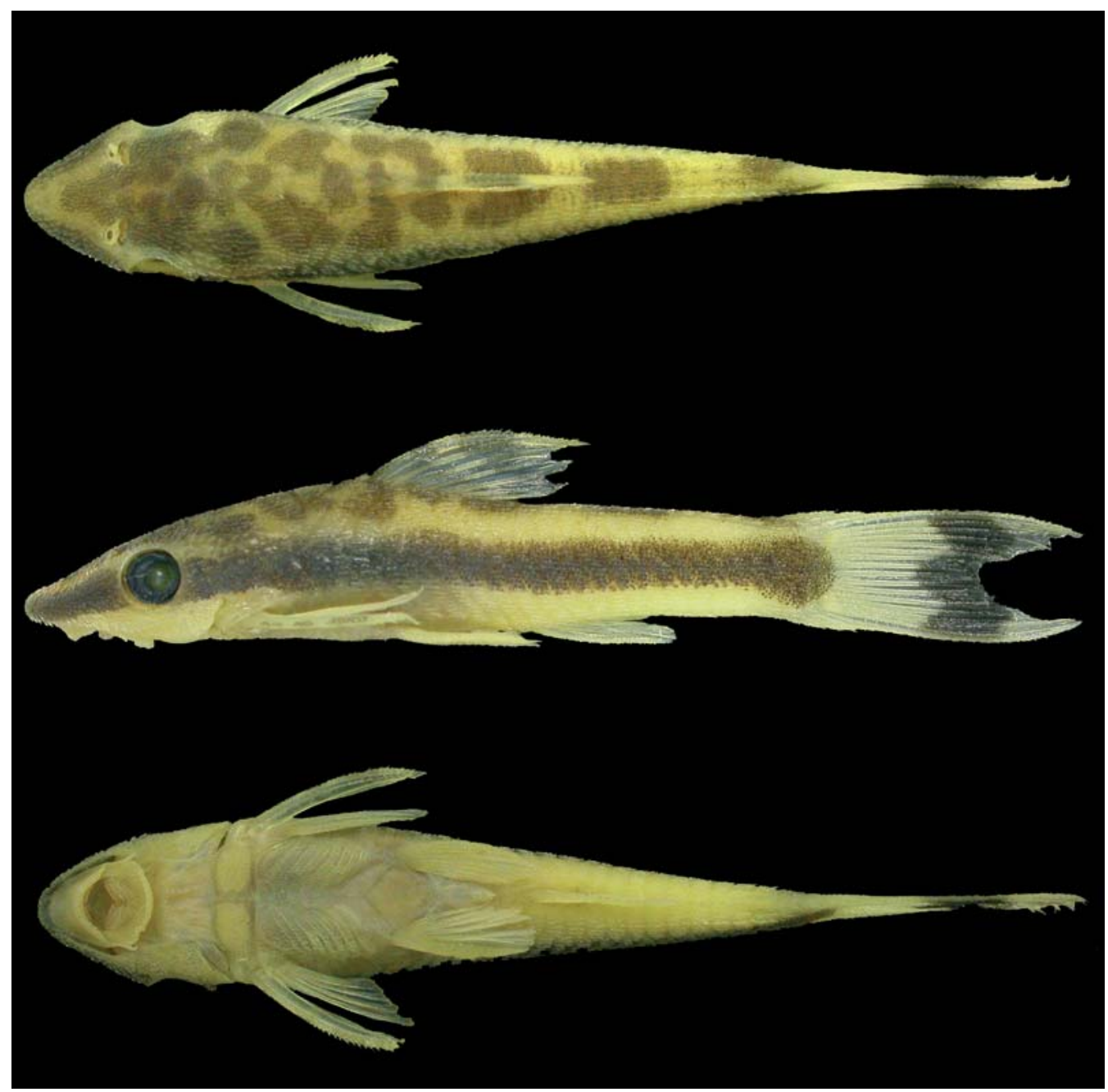

Fig. 1. Otocinclus batmani, ICNMHN 6721, holotype, male, $28.5 \mathrm{~mm} \mathrm{SL;} \mathrm{Colombia,} \mathrm{Amazonas,} \mathrm{small} \mathrm{stream} \mathrm{tributary} \mathrm{of} \mathrm{Río}$ Puré, Japurá drainage, upper Amazon basin.

Lateral margins of nuchal plate reduced, not expanded over transverse processes of first dorsal-fin radial. Dorsal fin II, $7 *(9)$ or 8(1); pectoral fin I,6; pelvic fin i,5; anal fin i,5; caudal fin i,14,i*(9) or i,13,i(1). Dorsal and ventral caudal-fin lobes equal in length. Dorsal procurrent rays two or three, ventral procurrent rays two or three. Vertebrae 22, excluding those incorporated into Weberian complex.

Color in alcohol. Ground color pale yellow. Complex pattern of melanophores along entire dorsal surface of head and trunk; occasionally concentrated in diffuse clusters between supraoccipital and dorsal-fin origin and with three discrete bands along midline between dorsal-fin base and caudal fin. Head and trunk with distinct midlateral stripe composed of superficial and deep-lying melanophores extending from snout (pre-nasal plates) to base of caudal-fin rays; pigment especially concentrated in region immediately ventral to margin of pterotic-supracleithrum and posterior to dorsal margin of opercle. Caudal fin with one W-shaped vertical mark in distal half, heavily pigmented, from middle portion to poste- rior fin margin. Pigmentation along median rays between caudal-fin base and W-shaped mark always absent. Modally three uppermost and three lowermost caudal-fin rays with unpigmented tips. Middle rays 4-11 typically pigmented to distal margin. Pigmentation in dorsal fin concentrated in 3-4 distinct blotches along spine; two bands on branched rays; interradial membranes unpigmented. Anal fin unpigmented. Pectoral fin with 3-4 blotches along spine; branched rays and interradial membranes unpigmented. Pelvic fin unpigmented. Ventral surface of head and body mostly unpigmented (Fig. 1).

Distribution. Otocinclus batmani is known from the typelocality, a small stream tributary to the Río Puré in Colombia, and from two creeks emptying into the Río Amazonas near Iquitos, Peru, in the upper Amazon River basin (Fig. 2).

Etymology. The name batmani, alludes to Bob Kane's hero Batman of the comic adventures, which had a bat shape for his symbol, referring to the single $\mathrm{W}$ - or bat-shaped vertical spot on the caudal-fin. 


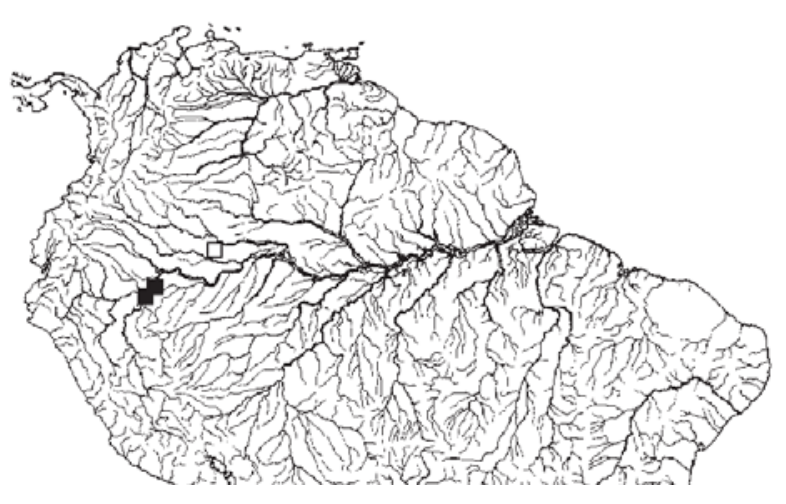

Fig. 2 Geographic distribution of Otocinclus batmani. Open symbol is type locality.

\section{Discussion}

This new species is most probably closely related to the clade B of Schaefer (1997: 103), which originally included Otocinclus bororo, O. mariae, O. mura, and O. huaorani, supported by the presence of 20 or more teeth in both the premaxilla and dentary (character 27). Otocinclus cocama also shares more than 20 teeth on upper and lower jaws, and should be included in the clade B as well. Within this group, the new species shares with $O$. cocama the presence of a single, intensely pigmented W-shaped caudal fin spot, which is here identified as a synapomorphy uniting these two species.

The first anal-fin pterygiophore is exposed ventrally in Otocinclus batmani, O. hasemani, O. hoppei, O. huaorani, $O$. macrospilus, O. mariae, O. mura, and O. vittatus. In callichthyids, Astroblepus, delturines and neoplecostomines, the first anal-fin pterygiophore is covered by skin. In all members of the Loricariinae (Paixão, 2004) and Hypoptopomatinae, except for some Otocinclus species, and the Otothyrini sensu Schaefer (1998), the first anal-fin pterygiophore is exposed ventrally. Paixão (2004; character 67) proposed the first analfin pterygiophore exposed ventrally and with plates around it (state 2) as a synapomorphy for the Loricariinae. However, in most hypoptopomatines examined, the same condition was observed. This character may represent an informative condition among neoplecostomines and hypoptopomatines (Lehmann \& Reis, in progress). Thus, the phylogenetic information of this feature should be verified in a future work on a revision of hypoptopomatines.

In callichthyids and most loricariids (Armbruster, 2004) the first dorsal-fin spine is a short, V-shaped structure, involved in the locking mechanism of the dorsal-fin spine in an upright position. In most otothyrins and some neoplecostomines, the spinelet is a rectangular, plate-like structure, and is not functionally a locking mechanism of the dorsal-fin spine. This spinelet is absent in all hypoptopomatins, but is present in all Otocinclus species (including the new species), which have a V-shaped spinelet and funtional locking mechanism of the dorsal-fin spine.
Table 2. Morphometric data for Otocinclus batmani. Values are given for the holotype (ICNMHN 6721) and nine paratypes $(\mathrm{n}=10) . \mathrm{SOC}=$ supraoccipital posterior process.

\begin{tabular}{|c|c|c|c|c|}
\hline & Holotype & Range & Mean & SD \\
\hline Standard length $(\mathrm{mm})$ & 28.5 & $23.2-36.7$ & 28.9 & - \\
\hline \multicolumn{5}{|c|}{ Percents of standard length } \\
\hline Body depth & 20.4 & $20.4-24.1$ & 22.0 & 1.5 \\
\hline Trunk depth at anal-fin origi & 18.2 & $18.2-22.6$ & 20.2 & 1.4 \\
\hline Caudal peduncle depth & 14.7 & $14.1-19.8$ & 15.9 & 1.4 \\
\hline SOC to dorsal-fin origin & 13.9 & $8.3-19.6$ & 14.3 & 1.8 \\
\hline Cleithrum to pelvic origin & 13.9 & $12.8-17.9$ & 15.4 & 1.3 \\
\hline Pelvic- to anal-fin origin & 17.7 & $17.6-22.5$ & 19.7 & 1.4 \\
\hline Trunk length & 47.3 & $43.2-50.8$ & 49.0 & 2.8 \\
\hline Head Length & 33.8 & $25.1-35.5$ & 29.1 & 0.6 \\
\hline \multicolumn{5}{|c|}{ Percents of head length } \\
\hline Snout width & 39.9 & $31.8-55.4$ & 43.5 & 0.7 \\
\hline Interorbit width & 51.0 & $50.4-76.1$ & 62.8 & 1.1 \\
\hline Internasal width & 20.0 & $15.0-37.2$ & 25.2 & 0.7 \\
\hline Nares diameter & 8.9 & $6.7-13.7$ & 10.1 & 0.2 \\
\hline Orbit diameter & 23.2 & $21.1-27.4$ & 24.7 & 0.3 \\
\hline
\end{tabular}

Comparative material: Otocinclus affinis: Brazil: Rio de Janeiro: UFRJ 4660, 2 c\&s, 28.8-30.7 mm SL, rio Preto, tributary to rio Piabanha, São José do Rio Preto, approx. $22^{\circ} 10^{\prime}$ S $42^{\circ} 55^{\prime} \mathrm{W}$. Otocinclus arnoldi: Brazil, Rio Grande do Sul, rio Uruguay drainage: MCP 25234, 8, 2 c\&s, 32.7-44.3 mm SL, rio Inhacunda, São Francisco de Assis, $29^{\circ} 32^{\prime} 27^{\prime \prime S} 55^{\circ} 07^{\prime} 45^{\prime \prime} \mathrm{W}$. MCP 25245, 46, 1 c\&s, 30.1-42.7 mm SL, stream tributary of rio Inhacunda, São Francisco de Assis, 29³2’39"S 5507' 50"W. MCP 26833, 1, $26.3 \mathrm{~mm}$ SL, creek tributary of rio Santa Maria, Rosário do Sul,30¹0`44"S 5451'22"W. MCP 26970, 1, 24.5 mm SL, rio Caxambú, Panambi, $28^{\circ} 35^{\prime} 50^{\prime \prime S} 53^{\circ} 27^{\prime} 31^{\prime \prime W}$. MCP 34613, 20, 19.9-24.5 mm SL, rio Ibicuí, São Vicente do Sul, 2448'00"S 5458'00"W. MCP 26864 , 8, 2 c\&s, 20.7-31.9 mm SL, arroio do Salso, Rosário do Sul,

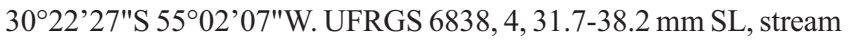
on road BR-290, $10 \mathrm{~km}$ from Rosário do Sul, 30¹2’43"S 5503'17"W. Argentina: MCP 32565, 5, 1 c\&s, 27.3-34.3 mm SL, Arroyo Nogoya, Entre Rios, approx. 3250'S 5950'W. MZUSP 51092, 18, Río Cayasta, tributary to Río San Javier, Santa Fé, approx. $31^{\circ} 10^{\prime} \mathrm{S} 60^{\circ} 10^{\prime} \mathrm{W}$. Uruguay: MCP 10003, 5, 29.9-36.5 $\mathrm{mm}$ SL, rio Negro, Cerro Largo, Arreria, approx. $31^{\circ} 50^{\prime} \mathrm{S} 54^{\circ} 28^{\prime} \mathrm{W}$. Otocinclus bororo: Brazil: Mato Grosso: MCP 15721, 5, 2 c\&s paratypes, 19.1-26.6 mm SL, creek on road from Barra do Bugres to Cáceres, approx. $15^{\circ} 45^{\prime} \mathrm{S} 57^{\circ} 20^{\prime} \mathrm{W}$. Otocinclus caxarari: Brazil: Mato Grosso: MCP 19286, 7, 2 c\&s paratypes, 21.4-25.7 mm SL, tributary to rio Guaporé, Guajará-Mirim, approx. $10^{\circ} 48^{\prime} \mathrm{S} 65^{\circ} 23^{\prime} \mathrm{W}$. Otocinclus cocama: Peru: Loreto: MCP 34842, 8, 2 c\&s paratypes, 29.7-40.7 mm SL, Quebrada Yanayacu, Jenaro Herrera, 0453'55"S 73³9'00"W. Otocinclus flexilis: Brazil, Rio Grande do Sul, laguna dos Patos system: MCP 21426, 2, 28.4-33.9 mm SL, arroio Arambaré, Pedro Osório, 3154'31"S 5301'44"W. MCP 18307 , 2, 37.6-37.8 mm SL, arroio Sapucaia, Esteio, approx. 2952’S $51^{\circ} 09^{\prime} \mathrm{W}$. MCP 9628, 3, 22.1-23.1 mm SL, arroio dos Ratos, Arroio dos Ratos, approx. $30^{\circ} 07^{\prime} \mathrm{S} 51^{\circ} 43^{\prime} \mathrm{W}$. MCP 25131, 1, $37.5 \mathrm{~mm} \mathrm{SL}$, arroio Arambaré, Pedro Osório, 3154'35"S 5301'40"W. MCP 17414, 13, 2 c\&s, 23.5-45.1 mm SL, arroio Itaetá, Passo das Pedras, 31 50 'S 52 43 'W. UFRGS 4963, 22, 23.5-31.0 mm SL, varzea of rio Gravataí, Porto Alegre. Otocinclus hasemani: Brazil: Piauí: MCP 22547, 94, 21.0-27.9 mm SL, riacho Palo, Formosa, 05¹4’27"S 4240'19"W. Otocinclus hoppei: Brazil: Pará: MCP 22545, 26, 23.8$32.1 \mathrm{~mm}$ SL, igararé Apeú, tributary to rio Guamá, Castanhal, 01¹8'06"S 4759'11"W. Otocinclus huaorani: Peru: Loreto: NRM 
17994, 13, 21.8-29.0 mm SL, and NRM 37375, 3 c\&s, 18.0-29.3 mm SL, quebrada at $\mathrm{km} 53$, San Jacinto, approx. $02^{\circ} 31^{\prime} \mathrm{S} 75^{\circ} 43^{\prime} \mathrm{W}$. Otocinclus macrospilus: Colombia, Amazonas, Río Amazonas drainage: ICNMHN 4155, 5, 27.3-37.3 mm SL, and ICNMHN 5213, 4, 23.6-31.2 mm SL, Quebrada Yahuaracaca, km 8, Letícia, 0408’05"S 6956’32"W. ICNMHN 5030, 1, 30.3 mm SL, Río Puré, Leticia, $02^{\circ} 07^{\prime} 05^{\prime \prime S} 69^{\circ} 37^{\prime} 50^{\prime \prime} \mathrm{W}$. Peru, Loreto, Iquitos, Río Amazonas drainage: MCP 28205, 1, $23.3 \mathrm{~mm}$ SL, Quebrada Pintuyacu, $43 \mathrm{~km}$ SW from Iquitos on road to Nauta, $04^{\circ} 5^{\prime} 58^{\prime \prime S} 73^{\circ} 27^{\prime} 18^{\prime \prime} \mathrm{W}$. Otocinclus mimulus: Paraguay: NRM 42332, 13 paratypes, 30.1$36.9 \mathrm{~mm} \mathrm{SL}$, and NRM 43479, 1 paratype c\&s, $36.2 \mathrm{~mm} \mathrm{SL}$, small stream at Estancia María Belén $8 \mathrm{~km}$ from Coronel Patricio Colman, Caaguazu, 2540'13"S 5505'52"W. Otocinclus mura: Brazil: Pará: MCP 22550, 19, 21.2-32.7 mm SL, Igarapé Urucuré, Tomé-Acú, 02`29'13"S 48³1'31"W. Otocinclus tapirape: Brazil: Goiás: UFRJ 5421, 2 c\&s, 20.1-20.3 mm SL, córrego Água Parada, $11 \mathrm{~km} \mathrm{~W} \mathrm{of}$ Novo Planalto, approx. $13^{\circ} 17^{\prime} \mathrm{S} 49^{\circ} 62^{\prime} \mathrm{W}$. Otocinclus vestitus: Colômbia: ICNMHN 4981, 1, 23.6 mm SL, Caño La Arenosa, 10 $\mathrm{km} \mathrm{S}$ on road Leticia to Tarapacá, approx. $04^{\circ} 8^{\prime} \mathrm{S} 69^{\circ} 56^{\prime} \mathrm{W}$. Otocinclus vitattus: Colombia: ICNMHN 1316, 1, $20.6 \mathrm{~mm} \mathrm{SL}$, Laguna de Menegua, Puerto Lopez, approx. 040'ㅇ $72^{\circ} 54^{\prime} \mathrm{W}$. Venezuela: MCNG 15667 (16, 9.1-25.8 mm SL) Caño Maraca, on road Guanare to Guanarito, approx. $08^{\circ} 50^{\prime} \mathrm{N} 69^{\circ} 21^{\prime} \mathrm{W}$. Otocinclus xakriaba: Brazil: Minas Gerais: MCP 23506, 1 c\&s, 30.2 mm SL, rio Paraopeba, Juatuba, approx. $19^{\circ} 57^{\prime} \mathrm{S} 44^{\circ} 18^{\prime} \mathrm{W}$. MCP 16879 , 25, 4c\&s, 22.53-28.68 mm SL, rio Peru-Açu, Januária, approx. $15^{\circ} 11^{\prime} \mathrm{S} 44^{\circ} 12^{\prime} \mathrm{W}$. Hypoptopoma guenteri: Brazil: Mato Grosso: MCP 15744, 2 c\&s, 49.1-52.75 mm SL, flooded area of Rio Pargauay, channel in the middle course, Cáceres, approx. $16^{\circ} 3^{\prime} \mathrm{S} 57^{\circ} 42^{\prime} \mathrm{W}$. Parotocinclus maculicauda: Brazil: Santa Catarina: MCP 10990, 2 c\&s, 39.5-43.5 mm SL, rio Iatapocú, Corupá, approx. $26^{\circ} 26^{\prime} \mathrm{S}$ 4912'W. Parotocinclus prata: Brazil: Minas Gerais: MCP 27381, 1 paratype c\&s, $29.1 \mathrm{~mm}$ SL, headwaters of rio da Prata, stream tributary of ribeirão Quiricó, fazenda São Zeferino, near Galena, Presidente Olegário, approx. $18^{\circ} 22^{\prime} \mathrm{S} 46^{\circ} 14^{\prime} \mathrm{W}$. Kronicthys lacerta: Brazil: Paraná: MCP 21664, 1 c\&s, 68.1 mm SL, rio Araracuara, 8 km N of Garuva, Guaratuba, 255 ' $58^{\prime \prime S} 48^{\circ} 49^{\prime} 43^{\prime \prime W}$. Kronicthys heilandi: Brazil: Rio de Janeiro: MZUSP 27545, $1 \mathrm{c \& s}, 61.2 \mathrm{~mm}$ SL, rio Pereque-Açu, on road Parati to Cunha, Parati, approx. $23^{\circ} 15^{\prime} \mathrm{S} 44^{\circ} 43^{\prime} \mathrm{W}$.

\section{Acknowledgements}

I thank Ivan Mojica and Claudia Castellanos (ICNMHN) for the loan of specimens, John Lynch (ICNMHN) for the information about the type locality of the new species, Donald Taphorn (MCNG), Marcelo Britto (MNRJ), Wilson Costa (UFRJ), Cristiano Moreira and Osvaldo Oyakawa (MZUSP), and Sven Kullander (NRM) for loan of comparative material, and Mark Sabaj (ANSP) for the loan of additional material, Edson Pereira (MCP) for comparative information on Neoplecostomine catfishes, to Roberto Reis (MCP) and Vinicius Bertaco (MCP) for comments and suggestions on the manuscript. Thanks also to Tiago Carvalho and all col- leagues in the Laboratory of Ichthyology, and Dr. Jeter Bertoletti director of Museu de Ciências e Tecnologia da PUCRS. Thanks to Thomas C. King (Rights \& Permission, DC Comics). This study was partially supported by a $\mathrm{PhD}$ grant from CNPq/CAPES - IEL Nacional - Brasil (process \# 190033/02-9).

\section{Literature Cited}

Armbruster, J. W. 2004. Phylogenetic relationships of the suckermouth armoured catfishes (Loricariidae) with emphasis on the Hypostominae and the Ancistrinae. Zoological Journal of the Linnean Society, 141: 1-80.

Axenrot, T. E. \& S. O. Kullander. 2003. Corydoras diphyes (Siluriformes: Callichthyidae) and Otocinclus mimulus (Siluriformes: Loricariidae), two new species of catfishes from Paraguay, a case of minetic association. Ichthyological Exploration of Freshwaters, 14(3): 249-272.

Britto, M. R. \& Moreira. 2002. Otocinclus tapirape: a new hypoptopomatine catfish from central Brazil (Siluriformes: Loricariidae). Copeia, 2002: 1063-1069.

Douglas, R. H., S. P. Collins \& J. Corrigan. 2002. The eyes of suckermouth armoured catfish (Loricariidae, subfamily Hypostomus): pupil response, lenticular longitudinal spherical aberration and retinal topography. Journal of Experimental Biology, 205:3425-3433.

Paixão, C. A. 2004. Revisão taxonômica e análise filogenética das espécies de Lamontichthys (Siluriformes: Loricariidae) Mirandaribero, 1939. Unpublished M.Sc. Thesis, Universidade de São Paulo, Brazil, 268p.

Reis, R. E. 2004. Otocinclus cocama, a new uniquely colored loricariid catfish from Peru (Teleostei: Siluriformes), with comments on the impact of taxonomic revisions to the discovery of new taxa. Neotropical Ichthyology, 2(3): 109-115.

Schaefer, S. A. 1997. The neotropical cascudinhos: systematics and biogeography of the Otocinclus catfishes (Siluriformes: Loricariidae). Proceedings of the Academy of Natural Sciences of Philadelphia, 148: 1-120.

Schaefer, S. A. 1998. Conflict and resolution: impact of new taxa on phylogenetic studies of the Neotropical cascudinhos (Siluroidei: Loricariidae), p. 375-400. In: Malabarba, L., R. Reis, R. Vari, Z. Lucena \& C. Lucena (eds.). Phylogeny and classification of Neotropical fishes. Porto Alegre. Edipucrs.

Schaefer, S. A. 2003. Subfamily Hypoptopomatinae. Pp. 321-329. In: R. E. Reis, S. O. Kullander \& C. J. Ferraris (Eds). Check list of the freshwater fishes of South and Central America. Edipucrs, Porto Alegre, 729p.

Taylor, W. R. \& G. C. Van Dyke. 1985. Revised procedures for staining and clearing small fishes and other vertebrates for bone and cartilage study. Cybium, 9: 107-119.

Submitted August 2006 Accepted December 2006 